\title{
Biological Studies on the Phytosiid Predator Amblyseius cucumeris (Oudemans) Reared on the Two Spotted Spider Mite Tetranchus urtica Koch EL-Naggar, M. E. ${ }^{1}$; S. S. Awadalla ${ }^{2}$; Hala A. El-Serfi ${ }^{2}$ and Marwa G. El-Mesawy ${ }^{1}$ ${ }^{1}$ Plant Protection Institute, Agriculture Research Center. \\ ${ }^{2}$ Economic Entomology Dep. Faculty of Agriculture, Mansoura Unviersity.
}

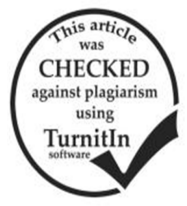

\section{ABSTRACT}

This experiment was conducted to study the effect of different stages of the two spotted spider mite, T. urticae as prey on the biological aspects of the predacous mite, Amblyseius cucumeris at the laboratory conditions, 20 and $30^{\circ} \mathrm{C}$ and $75 \%$ R.H. The incubation period of A. cucumeris averaged 3.2 and 3.3 days for the eggs of adult females fed on the adult and immature stages of T. urticae, at 20 ${ }^{\circ} \mathrm{C}$, respectively. This period did not obviously changed with temperature increase, recorded 2.23 and 2.23 days, at $30{ }^{\circ} \mathrm{C}$., respectively. The mean larval period of female and male of the predator recorded the longest period when the female indivduals fed on immature stages of T. urticae at $20^{\circ} \mathrm{C}$. While the shortest period when the male indivduals fed on the adult stages of T. urticae at $20^{\circ} \mathrm{C}$. The protonymphal period of the phytoseiid mite,durated the longest period 3.37 days when fed on Turticae immature stages at $20^{\circ} \mathrm{C}$, and the shortest period 2.26 days when fed on the adult stage at $30^{\circ} \mathrm{C}$. The longest deutonymphal period lasted 2.82 for male indivduals when fed on the adult stages at $20^{\circ} \mathrm{C}$, but the shortest deutonymphal period 1.4 days when fed on the same prey at $30^{\circ} \mathrm{C}$. Life cycle duarated an average of 10.52 and 12.81 days when female indivduals fed on T. urticae adult and immature stages at $20^{\circ} \mathrm{C}$, when reared at $20{ }^{\circ} \mathrm{C}$, but lasted an average of 8.92 and 10.07 days at $30^{\circ} \mathrm{C}$, respectively. The longest period of the longevity was observed for the female when fed on the adult stage at $20^{\circ} \mathrm{C}$, but the shortest period when the male fed on immature stages at $30^{\circ} \mathrm{C}$. The highest deposited eggs recorded when the female fed on the immature stages at $30^{\circ} \mathrm{C}$, but the lowest number of deposited eggs when female fed on the adult stage of T. urtica.

\section{INTRODUCTION}

The cucumber, Cucumis sativus L., is a new greenhouse crop which can be grown successfully under protective structures year-round. The cucumber has high climatic demands especially humidity, air temperature and light intensity, and these main factors affect cucumber crop quality and quantity, therefore, their instability during the changing season should be considered. The two-spotted spider mite, Tetranychus urticae Koch is one of the most destructive pests. The divers host plant species may have been differentially affected by this pest. Cucurbit vegetable crops are commonly planted in numerous districts of Egypt affected by this pest. Cucurbit crops are preferable for this pest which decreases its yield. The rpid developmental rate and high reproductive potential of $T$. urticae allow it achieve damaging population levels very quickly under suitable conditions, resulting in an equal rapid decline of host plant quality. Because of its short life cycle and high reproductive rates, spider mite develops resistance faster than most insects (Guo et al., 1998). Family Phytoseiidae contains a large number of species know to prey on spider and eriophyid mites, and there are numerous references indicating that certain species are important. Some phytoseiid seem to reproduce equally well on animal or non-animal foods (McMurry and Sciveen 1965a). Some others utilize such miscellaneous foods as fungi (Chant 1959), white flies (Teich 1966), moth eggs (Swirski et al., 1967a, b), thrips (Bonde 1989) and nematodes (Muma 1967a).Watanabe et al., (1994) tested technical viability using phytoseiid to control T. urticae in cucumber, only Amblyseius species was successfully established on cucumber, significantly reducing $T$. urticae population. So, the current study is conducted to study some of the biological aspects of the phytoseiid mite, Amblyseius cucumeris (Oudemans) at laboratory conditions.

\section{MATERIALS AND METHODS}

Amblyseius cucumeris newly deposited eggs were collected from cucumber plants in the experimental farm belonging to fauclty of griculture, Mansoura university and transferred to leaf cucumber discs, each disc one inch in diameter as rearing arenas in Peti-dishes on water saturated cotton and kept on 20 and $30{ }^{\circ} \mathrm{C}$. Each newly hatched larvae (25 replicates) was supplied with sufficient known number of preys (T. urticae adults and immature stages). All larvae were reared individually under the tested temperatures. Before the final molt of female, or male a introduced to the replicate for mating and removed after one day, experiment was observed twice a da. The number of laid eggs as well as consumption rate were counted daily until female dies. Longevity and consumption of adult male were also counted. The different of different reared female's predator stages were recorded. Eggs of the reared females were collected daily from each female and determined. The statistical analysis (ANOVA) and regression) of the obtained results were performed using SAS program (SAS Institute, 1988).

\section{RESULTS AND DISCUSSION}

The present study was conducted to determine the effect of different temperatures and prey type on the duration of various biological aspects of the predacious phytoseiid mite Amblyseius cucumeris.

\section{Incubation period:}

Incubation period of A. cucumeris averaged 3.2 and 3.3 days for the eggs of adult female fed on the adult and immature stages of $T$. urticae, at $20^{\circ} \mathrm{C}$, respectively, Table ( 1 ), this period recorded 2.23 and 2.23 days, at $30{ }^{\circ} \mathrm{C}$., respectively.

Larval stage:

The mean larval period of female and male $A$. cucumeris lasted the longest period when the female individuals fed on the immature stages of $T$. urticae and recorded 3.42 days, at $20{ }^{\circ} \mathrm{C}$ Table ( 1 ). However, the shortest period of $A$. cucumber averaged 1.4 when the male indivduals fed on the adult stages of T. urticae at $20^{\circ} \mathrm{C}$.

Protonymphal stage

As shown in Table (1). The protonymphal period of the phytoseiid mite, A. cucumeris durated an average of 
2.56 and 3.37 days when the indivduals fed on $T$ urticae adult and immature stages at $20{ }^{\circ} \mathrm{C}$, respectively. While, lasted 2.26 and 2.34 days when the same indivduals fed at $30^{\circ} \mathrm{C}$ on the adult and immature stages, respectively.

\section{Deutonymphal stage}

Data arranged in Table ( 1 ) showed that the longest period of A. cucumeris was lasted 2.82 for male indivduals when fed on the adult stages of T. urticae at 20 ${ }^{\circ} \mathrm{C}$, but the shortest deutonymphal period was recorded 1.4 days at $30^{\circ} \mathrm{C}$.

\section{Life cycle}

The obtained data in Table ( 1 ) showed that the predatory mite, A. cucumeris duarated an average of 10.52 and 12.81 days when female indivduals fed on T. urticae adult and immature stages at $20^{\circ} \mathrm{C}$, while lasted 8.92 and 10.07 days when reared at $30^{\circ} \mathrm{C}$, respectively. However, this period for the male predatory mites lasted 8.12, 9.47 days on $20^{\circ} \mathrm{C}$ and $5.39,9.17$ days on $30^{\circ} \mathrm{C}$, respectively.

\section{Longevity}

The average duration of the adult stages male and female of the phytoseiid mite, A. cucumeris were presented in Table (1). The longest period of the longevity was observed for the female indivduals of $A$. cucumeris when fed on the adult stage of $T$. urticae at $20^{\circ} \mathrm{C}$, but the shortest period was recorded when the male indivduals of $A$. cucumeris fed on immature stages of T. urticae at $30{ }^{\circ} \mathrm{C}$ and recorded 16.64 days.

Preoviposition, oviposition and postoviposition periods of $A$. cucumeris

As shown in Table ( 1 ) the longest preoviposition period of $A$. cucumeris was determined for the female indivduals fed on immature stages of T. urticae at $20^{\circ} \mathrm{C}$, but the shortest one was recorded when the female fed on the adult stages of T. urticae at $30^{\circ} \mathrm{C}$. However, the female took the longest oviposition period when fed on T. urticae adult at $20^{\circ} \mathrm{C}$, but the shortest time was recorded at $30{ }^{\circ} \mathrm{C}$ when the indivduals fed on the same prey and duarted 16.03 days.

\section{Fecundity}

The tabulated data in Table ( 1 ) showed that the highest deposited eggs for the predatory mite, $A$. cucumeris was noticed when the female fed on the immature stages of $\mathrm{T}$. urticae at $30 \mathrm{C}$, as, it laid an average of 52.6 eggs, but the lowest number of deposited eggs was recorded for the female when fed on the adult stages of $T$. urticae, as it laid an average of 37.0 eggs.

Food consumption of $A$. cucumeris when fed on different stages of $T$. urticae at different temperatures

The feeding capacity of A. cucumeris on T. urticae was affected by temperatures and also with the type of used preys, Table ( 2 ). The total consumed prey/predator decreased as temperature increased from 20 to $30{ }^{\circ} \mathrm{C}$ for predator female indivduals when fed on adult stages of the preyand devoured 146.6 and 142.3 adult preys, respectively, and 72.1 and 70.3 adult prey for the /predatory male, respectively. However, the number of devoured immature stages of T. urticae prey was high at 30 $\mathrm{C}$ than $20^{\circ} \mathrm{C}$ for both female and male indivduals of the predator, as, they consumed 148.5 and 34.6 immatures of the prey at 20 for female and males, respectively, and 151.3 and 68.7 immature stages of the prey, respectively at $30{ }^{\circ} \mathrm{C}$.

A high consumption rate also was recorded on eriophyid prey for Amblyseius gossipi (Reda and ELBagoury 1986) and Typhlodromus balanites (EL-Bagoury and Momen 1989).

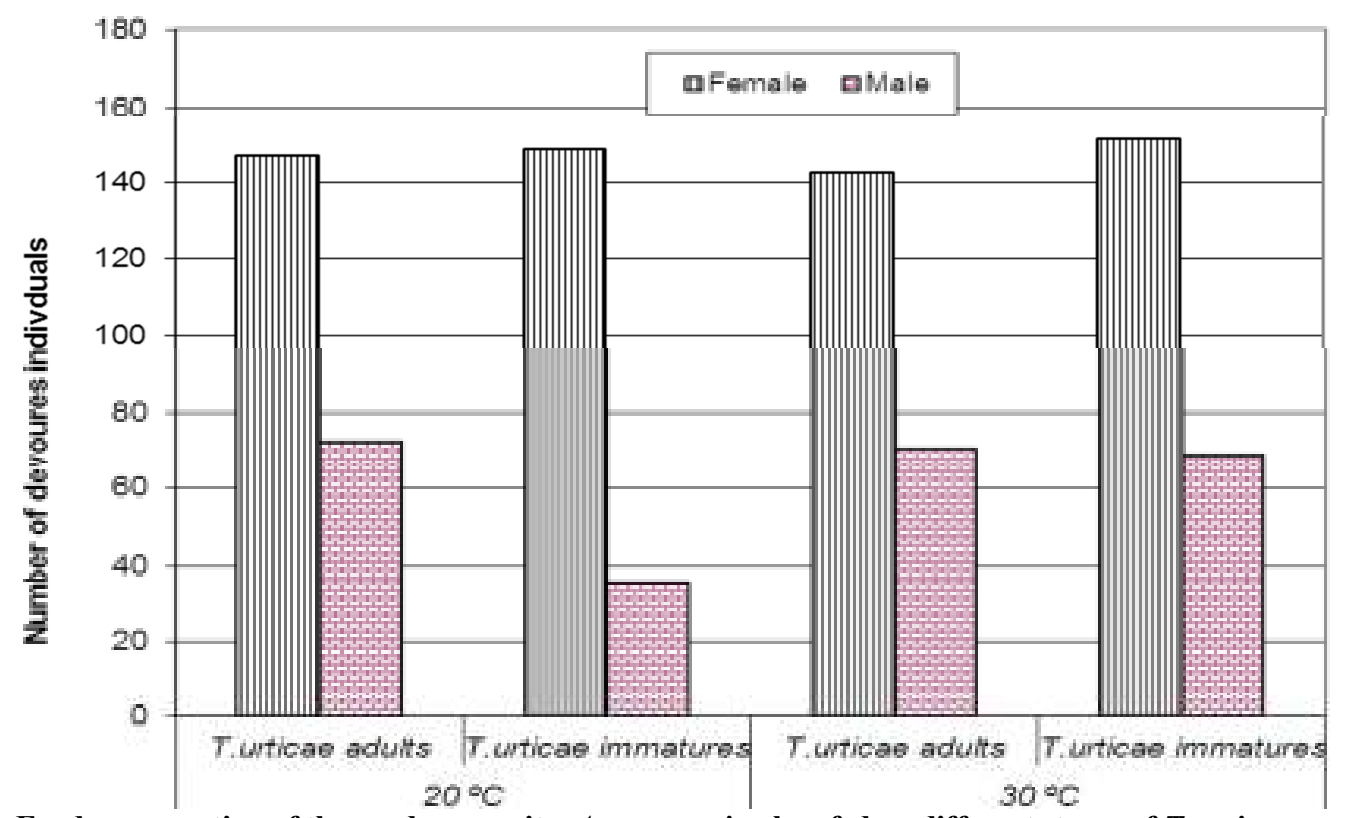

Fig.1. Food consumption of the predacous mite, A. cucumeris when fed on different stages of $T$. urticae as preys. 
Table 1. Duration (mean+SD) of different stages and fecundity of $A$. cucumeris when fed on $T$. urticae adult and immature sages

\begin{tabular}{|c|c|c|c|c|c|}
\hline \multirow[b]{2}{*}{ Predator stages } & \multirow[b]{2}{*}{ Sex } & \multicolumn{2}{|c|}{$20^{\circ} \mathrm{C}$} & \multicolumn{2}{|c|}{$30^{\circ} \mathrm{C}$} \\
\hline & & $\begin{array}{l}\text { T. urticae adult } \\
\text { stage }\end{array}$ & $\begin{array}{c}\text { T.uricae } \\
\text { immature stage }\end{array}$ & $\begin{array}{l}\text { T. urticae adult } \\
\text { stage }\end{array}$ & $\begin{array}{c}\text { T.uricae } \\
\text { immature stage }\end{array}$ \\
\hline \multirow{2}{*}{ Egg } & o & $3.2+0.32$ & $3.3+0.26$ & $2.23+0.15$ & $2.23+0.16$ \\
\hline & ह & $1.53 \pm 0.13$ & $2.58+0.08$ & $1.35 \pm 0.16$ & $2.34+0.06$ \\
\hline \multirow{2}{*}{ Larva } & q & $2.29 \pm 0.14$ & $3.42 \pm 0.21$ & $2.23 \pm 0.16$ & $2.48 \pm 0.09$ \\
\hline & $\hat{\sigma}^{2}$ & $1.4 \overline{+0} .08$ & $2.49 \pm 0.04$ & $1.37 \pm 0.17$ & $2.31 \pm 0.18$ \\
\hline \multirow{2}{*}{ Protonymph } & q & $2.5 \overline{6 \pm 0}+0.17$ & $3.37 \pm 0.26$ & $2.26 \pm 0.26$ & $2.34 \pm 0.10$ \\
\hline & ô & $2.3 \pm 0.18$ & $2.22 \pm 0.29$ & $1.28 \mp 0.17$ & $2.25 \mp 0.16$ \\
\hline \multirow{2}{*}{ Deutonymph } & q & $2.5 \pm 0.06$ & $2.66 \pm 0.07$ & $2.21 \pm 0.18$ & $2.47 \pm 0.09$ \\
\hline & o & $2.82 \pm 0.13$ & $2.12 \pm 0.05$ & $1.4 \pm 0.07$ & $2.32 \pm 0.17$ \\
\hline \multirow{2}{*}{ Total immature } & q & $7.35 \mp 0.45$ & $9.45 \pm 0.64$ & $6.7 \pm 0.36$ & $7.29 \pm 0.51$ \\
\hline & ô & $6.52 \pm 0.51$ & $6.83 \pm 0.57$ & $4.05 \pm 0.23$ & $6.88 \pm 0.49$ \\
\hline \multirow{2}{*}{ Life cycle } & q & $10.52 \pm 0.39$ & $12.81 \pm 0.29$ & $8.92 \pm 0.34$ & $10.07 \pm 0.30$ \\
\hline & $\hat{0}$ & $8.12 \pm 0.29$ & $9.47 \pm 0.16$ & $5.39 \mp 0.36$ & $9.17 \pm 0.44$ \\
\hline \multirow{2}{*}{ Longevity } & q & $24.1 \overline{6} \pm 0.86$ & $24.15 \pm 0.56$ & $19.52 \pm 0.74$ & $24.13 \pm 0.63$ \\
\hline & 齐 & $18.24 \pm 0.57$ & $17.98 \pm 0.52$ & $16.75 \pm 0.51$ & $16.64 \pm 0.35$ \\
\hline \multirow{2}{*}{ Life span } & q & $34.67 \pm 0.96$ & $37.01 \pm 0.53$ & $28.45 \pm 0.97$ & $34.2 \pm 0.58$ \\
\hline & $\hat{0}$ & $26.15+0.81$ & $27.24+0.84$ & $22.73+1.65$ & $25.8 \overline{1}+0.54$ \\
\hline Preoviposition & & $2.22 \pm 0.04$ & $2.65+0.23$ & $1.22 \pm 0.20$ & $2.27 \pm 0.73$ \\
\hline Oviposition & & $19.4 \overline{7 \pm} 0.82$ & $19.0 \overline{4 \pm} 0.67$ & $16.0 \overline{3 \pm} \pm 0.63$ & $18.7 \pm 0.50$ \\
\hline Postoviposition & & $2.41 \pm 0.17$ & $2.56 \pm 0.11$ & $2.36 \pm 0.28$ & $2.9 \pm 0.35$ \\
\hline Fecundity & & $37.0+0.156$ & $51.2 \overline{+} 2.44$ & $41.6+1.71$ & $52 . \overline{6}+1.65$ \\
\hline
\end{tabular}

Table 2 . Effect of different factors on the different biological aspects of the predacous mite $A$. cucumeris at 20 and $30{ }^{\circ} \mathrm{C}$

\begin{tabular}{|c|c|c|c|c|}
\hline Variable & Factor & F. & P. & L.S.D. at 0.05 level \\
\hline \multirow{3}{*}{ Incubation period } & Temp. & 29.17 & $0.000 * * *$ & \multirow{3}{*}{0.0783} \\
\hline & Diet & 568.17 & $0.000 * * *$ & \\
\hline & Sex. & 300.5 & $0.000 * * *$ & \\
\hline \multirow{4}{*}{ Larva } & Temp. & 98.704 & $0.000 * * *$ & \multirow{3}{*}{0.065} \\
\hline & Diet & 647.648 & $0.000 * * *$ & \\
\hline & Sex. & 450.729 & $0.000 * * *$ & \\
\hline & Temp. & 198.38 & $0.000 * * *$ & \multirow{3}{*}{0.082} \\
\hline \multirow[t]{3}{*}{ Protonymph } & Diet & 117.245 & $0.000 * * *$ & \\
\hline & Sex. & 227.082 & $0.000 * * *$ & \\
\hline & Temp. & 638.722 & $0.000 * * *$ & \multirow{3}{*}{0.054} \\
\hline \multirow[t]{3}{*}{ Deutonymph } & Diet & 8.046 & $0.0059 * *$ & \\
\hline & Sex. & 383.425 & $0.000 * * *$ & \\
\hline & Temp. & 618.28 & $0.000 * * *$ & \multirow{3}{*}{0.147} \\
\hline \multirow[t]{3}{*}{ Life cycle } & Diet & 834.54 & $0.000 * * *$ & \\
\hline & Sex. & 11.82 .8 & $0.000 * * *$ & \\
\hline & Temp. & 188.58 & $0.000 * * *$ & \multirow{3}{*}{0.272} \\
\hline \multirow[t]{3}{*}{ Longevity } & Diet & 60.46 & $0.000 * * *$ & \\
\hline & Sex. & 624.85 & $0.000 * * *$ & \\
\hline & Temp. & 279.9 & $0.000 * * *$ & \multirow{3}{*}{0.413} \\
\hline \multirow[t]{2}{*}{ Life span } & Diet & 218.59 & $0.000 * * *$ & \\
\hline & Sex. & 1524.37 & $0.000 * * *$ & \\
\hline
\end{tabular}

A carefully examination of the data arranged in Table (2) indicated that temperature and diets factors expressed as highly significant positive on the different biological aspects of the predacious mite, A. cucumeris adult stages males and females. L.S. D. at 0.05 level $=$ $0.783,0.147$ and 0.272 for incubation period, life cycle and longevity for both sexes (male and female), respectively. Also, from the statistical point of view, the simple correlation value, Table (3) was positive relationship with the female predacious mites fed on the adult stages of $T$. urticae for effect of both temperature degrees (20 and 30 ${ }^{\circ} \mathrm{C}$ ), but it was negative when fed on the immature stages of the introduced prey. On the other hand, the relation between temperature and the male individuals of the predacous mite was negative at $20^{\circ} \mathrm{C}$ when the mites fed on the adult stages of $T$. urticae and positive at $30{ }^{\circ} \mathrm{C}$. However, the effect of $30^{\circ} \mathrm{C}$ on the biological aspects of $A$. cucumeris male was positive when fed on prey adult stages and negative when the immature stages of $T$. urticae were introduced for the male predator as food source, Table (3)

Table 3. The correlation between the different factors affecting on the predacious mite A. cucumeris

\begin{tabular}{|c|c|c|c|c|c|}
\hline Sex & Prey stages & Temp. & Corr. & Slope & Y int (a) \\
\hline \multirow{4}{*}{ q } & \multirow[b]{2}{*}{ Adult stage of T. urticae } & $20^{\circ} \mathrm{C}$ & 0.049 & 0.023 & 2.244 \\
\hline & & $30^{\circ} \mathrm{C}$ & 0.606 & 0.656 & 0.76 \\
\hline & \multirow{2}{*}{ Immature stages of T. urticae } & $20^{\circ} \mathrm{C}$ & -0.563 & 1.0461 & 4.94 \\
\hline & & $30^{\circ} \mathrm{C}$ & -0.0649 & -0.080 & 2.703 \\
\hline \multirow{4}{*}{$\sigma^{\lambda}$} & \multirow{2}{*}{ Adult stage of T. urticae } & $20^{\circ} \mathrm{C}$ & -0.0988 & 0.0600 & 1.565 \\
\hline & & $30^{\circ} \mathrm{C}$ & 0.3361 & 0.3469 & 0.9016 \\
\hline & \multirow{2}{*}{ Immature stages of T. urticae } & $20^{\circ} \mathrm{C}$ & 0.1784 & 0.1028 & 2.2250 \\
\hline & & $30^{\circ} \mathrm{C}$ & -0.382 & -1.144 & 4.984 \\
\hline
\end{tabular}


Similar results were conducted by Zhang et al., (2000) who evaluated the potential of predatory mite Amblyseius cucumeris (Oudemans) in the laboratory to as a biocontrol agent against the spider mite Schizotetranychus nanjingensis Ma \& Yuan, a pest of the moso bamboo in Fujian, China. When fed S. nanjingensis females and eggs, the life cycle of A.cucumeris (developmental time from egg to egg 7.7 days for the first generation and 7.8 days for the second generation) was as long as its life cycle on its normal diet in the laboratory, Tyrophagus putrescentiae (Schrank) (7.8 days) at $27-28{ }^{\circ} \mathrm{C}$. Adult females of A. cucumeris started to lay eggs at the age of 3 days with a daily rate of 1-4 eggs (average of 2.2) over a period of 7-18 days and a total fecundity of 35.8 (14-47) eggs. The number of prey consumed by predators increased with prey density and the number of eggs produced was directly correlated with the number of prey consumed. Female predators consumed twice as many female spider mites as did male and deutonymph predators ( 6 versus 3 per day at 9 prey per leaf). The predatory mite Amblyseius cucumeris (Oudemans), sometimes cited in literature as Neoseiulus cucumeris, is such a predator.

It is abiocontrol agent widely used for the control of various species of thrips on cucumber and pepper in greenhouses through preventive, mass releases (Gillespie 1989; Bennison and Jacobson 1991 and Wada 1999).

One reported evaluation of it against the eriophyid mite Aculops lycopersici (Massee) showed that it failed to reproduce on this mite (Brodeur et al.1997). A. cucumeris was effective against the broad mite Polyphagotarsonemus latus (Banks) on reenhouse plants in China (L.R. Liang, personal communication).

\section{REFERENCES}

Bennison, J.A. and Jacobson, R. (1991). Integrated control of Frankliniella occidentalis (Pergande) in UK cucumber crops - evaluation of a controlled release system of introducing Amblyseius cucumeris Mededelingen van de Faculteit and bouwwentenschappen, Riijsuniversityteit Gent , 56(2a), 251-258.

Bonde, J. (1989) Biological studies including population growth parameters of the predatory mite Amblyseius barkeri (Acarina: Phytoseiidae) at $25^{\circ} \mathrm{C}$ in the laboratory. Entomophaga 34, 275-287.

Brodeur, J., Bouchard, A. \& Turcotte, G. (1997). Potential of four species of predatory mites as biological control agents of the tomato russet mite, Aculops lycopersici (Massee) (Eriophyidae). Canadian Entomologist, $129,1-6$
Chant, D. A. (1959). Phytoseiid mites (Acarina: Phytoseiidae). The Memoirs of the Entomological Society of Canada, 91(S12), 5-166.

EL-Bagoury, M. E. and Momen, F.M. (1989). Typhlodromus balanites (Acarina: Phytoseiidae) as a predator of the gall mite Eriophyes dioscoridis (Acarina: Eriophyidae). -Ann. Agric. Sci. Moshtohor 27 (4): 2513-2520.

Gillespie, D.R. (1989). Biological control of thrips (Thysanoptera: Thripidae) on greenhouse cucumber by Amblyseius cucumeris Entomophaga, 34,185192.

Guo F, Zhang Z and Zhao Z (1998). Pesticide resistance of Tetranychus cinnabarinus (Acari: Tetranychidae) in China: a review. Systematic Appl. Acarol.,3: 3-7.

McMurtry, J. A. and Scriven, G. T. (1965). Life history studies of Amblyseius Limonicus with comparative observations of Amblyseius hibisci (Acarina: Phytoseiidae). Ann. Ent. Soc. Amer., 8 : 106-111.

Muma, M. H. (1967). "Basic behavior of North American Solpugida". Florida Entomologist. 50 (2): 115-123.

Reda, A. S. and EL-Bagoury, M. E. (1986). Effect of the gall mite Eriophyes dioscoridis (Eriophyidae) on the development and reproduction of the predacious mite Amblyseius gossipi (Acarina: Phytoseiidae). Bull. Fac. Agric. Univ. Cairo 37: 503-507.

SAS institute (1988). SAS/Stat users guide, 6.03 ed. SAS Institute, Cary, NC.

Swirski, E., S. Amitai and N. Dorzia (1967a). Laboratory studies on the feeding, development and reproduction of predaceous mites Amblvseius rubini Swirski \& Amitaiand Amblyseius swirskii Athias [Acarina: Phytoseiidae 1 on various kinds of food substances. Israel J. agric. Res.,17, 101-119.

Teich, Y. (1966). Mites of the family of Phytoseiidae as predators of the tobacco whitefly, Bemisia tabaci Gennadius. Israel J. Agric. Res. 16: 141-142.

Wada, T. (1999). Development of Cucumeris and its future prospect. Agrochemicals Japan , 73, 17-19.

Watanabe MA, Moraes GJD, Gastaldo J (1994). Biological control of the two-spotted spider mite (Acari: Tetranychidae, Phytoseiidae) in cucumber and strawberry crops. Scientia Agricola, 51(1): 75-81.

Zhang, Y.; ZHANG, Z. ; , LIN. J. and Jie, J. (2000). Potential of Amblyseius cucumeris (Acari: Phytoseiidae) as a biocontrol agent against Schizotetranychus nanjingensis (Acari: Tetranychidae) in Fujian, China. Systematic \& Applied Acarology Special Publications, 4, 109-124

\footnotetext{
دراسات بيولوجية على المفترس Amblyseius cucumeris عند تربيته على العنكبوت الاحمر ذو البقعتين Tetranychus urticae KOCH

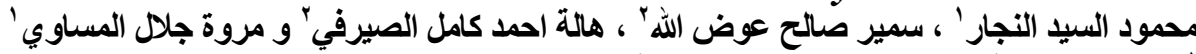

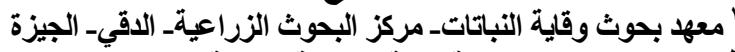

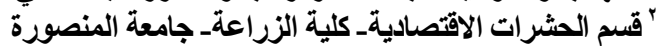

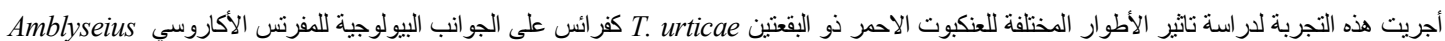

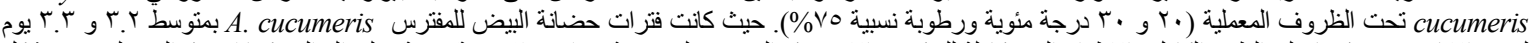

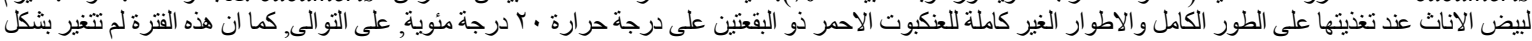

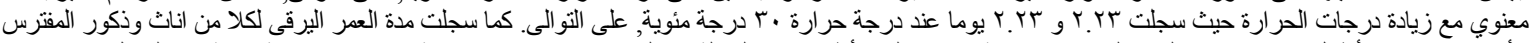

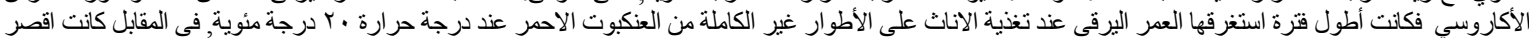

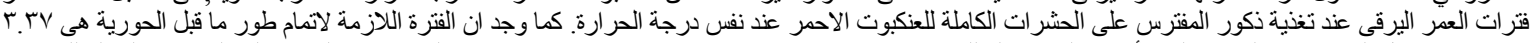

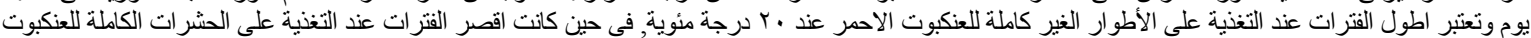

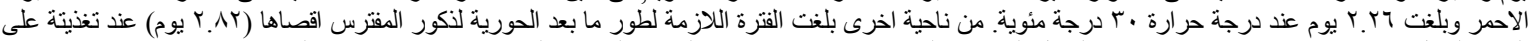

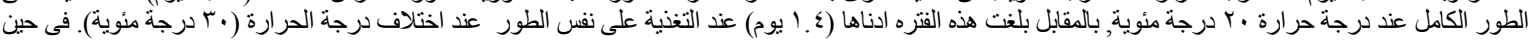

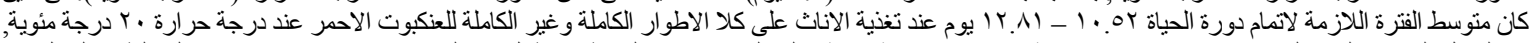

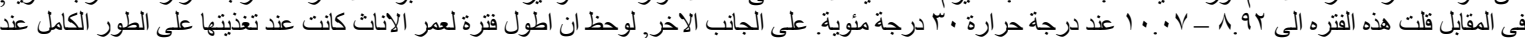

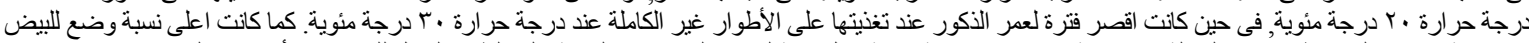

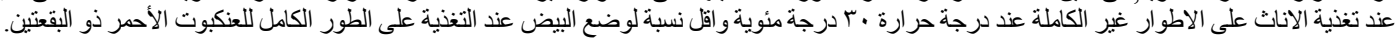

